\title{
AMMONIA NITROGEN DESORPTION FROM SANITARY LANDFILL LEACHATE IN FILLING TOWERS
}

\section{VALDERI D. LEITE ${ }^{1}$, ALDRE J. M. BARROS ${ }^{2}$, WILTON S. LOPES ${ }^{3}$, JOSÉ T. DE SOUSA ${ }^{4}$}

ABSTRACT: Sanitary landfill leachates present high concentrations of carbonaceous and nitrogenous materials. The crucial point is that carbonaceous materials are of difficult biodegradation, what compromises the performance of biological treatment processes, while nitrogenous materials, such as ammonia nitrogen, probably preclude the use of biological treatments. Therefore, the aim of this work was to study the desorption process of ammonia nitrogen from sanitary landfill leachate in filling towers. Desorption was carried out in filling towers of $35 \mathrm{~L}$ capacity. The leachate was collected from a sanitary landfill located in João Pessoa, Paraíba State, Brazil. Desorption efficiency for the $\mathrm{pH}$ values adopted in four treatments was 93\% minimum and $95.5 \%$ maximum, with aeration mean time ranging from 3 to 6 hours. The limiting factors of ammonia nitrogen desorption from sanitary landfill leachates in filling towers are associated with the use of alkalizer species for $\mathrm{pH}$ correction, and electricity costs for aeration.

KEYWORDS: leachate, ammonia nitrogen, filling tower, desorption.

\section{DESSORÇÃO DE NITROGÊNIO AMONIACAL DE LIXIVIADO DE ATERRO SANITÁRIO EM TORRES DE RECHEIO}

RESUMO: Lixiviado advindo de aterro sanitário é detentor de elevada concentração de material carbonáceo e nitrogenado. A questão crucial é que o material carbonáceo presente é de difícil biodegradação, o que compromete o desempenho do processo de tratamento biológico, enquanto o material nitrogenado se encontra na forma de nitrogênio amoniacal, o que provavelmente inviabiliza o emprego do processo de tratamento biológico. Portanto, o objetivo deste trabalho foi estudar o processo de dessorção de nitrogênio amoniacal presente em lixiviado de aterro sanitário em torres de recheio. $O$ processo de dessorção de nitrogênio amoniacal foi realizado em torres de recheio com capacidade unitária de 35 litros. O lixiviado utilizado para estudo do processo de dessorção de nitrogênio amoniacal foi coletado no aterro sanitário da cidade de João Pessoa, capital do Estado da Paraíba. A eficiência mínima de dessorção de amônia foi de 93\%, e a máxima, de 95,5\%, para os valores de $\mathrm{pH}$ adotados nos quatro diferentes tratamentos, com tempo médio de aeração variando de 3 a 6 horas. Salienta-se que os fatores limitantes do processo de dessorção de nitrogênio amoniacal de lixiviado de aterro sanitário, em torre de recheio, estão associados ao emprego de espécies alcalinizantes para a correção do $\mathrm{pH}$ e ao custo de energia elétrica para aeração.

PALAVRAS-CHAVE: lixiviado, nitrogênio amoniacal, torre de recheio, dessorção.

\section{INTRODUCTION}

The population exponential growth, rapid world urbanization and industrialization, and natural absorption capacity of solid residues cause environmental saturation, thus generating negative impacts of several magnitudes (YE et al., 2011).

\footnotetext{
${ }^{1}$ Engo Químico, Prof. Dr., Depto. de Eng. Sanitário e Ambiental, CCT/UEPB, Campina Grande - PB, Fone: (83) 3315-3352, valderileite@uol.com.br

${ }^{2}$ Químico Industrial, Prof. Dr., Unidade Acadêmica de Tecnologia do Desenvolvimento, CDSA/UFCG, Sumé - PB, Fone: (83) 3353-1850, aldrejmb@ufcg.edu.br

${ }^{3}$ Químico Industrial, Prof. Dr., Depto. de Eng. Sanitário e Ambiental, CCT/UEPB, Campina Grande - PB, wilton@uepb.edu.br

${ }^{4}$ Eng $^{\circ}$ Químico, Prof. Doutor, Depto. de Eng. Sanitária e Ambiental, CCT/UEPB /Campina Grande - UF, tavaresuepb@gmail.com

Recebido pelo Conselho Editorial em: 28-9-2012

Aprovado pelo Conselho Editorial em: 9-1-2014
} 
In Brazil, around 260,000 tons of urban solid residues are collected daily. From this amount, about 35,000 tons are taken to sanitary landfills producing byproducts as biogas and leachates (LEITE et al., 2011).

Sanitary landfills are the most world used disposal technique of municipal solid waste (MSW) (MOHAJERI et al., 2010), since they tolerate great amounts of solid residues at relatively low costs (UMAR et al., 2010; CASTRILLÓN et al., 2010). According to ABBAS et al. (2009) and COTMAN et al. (2010), sanitary landfills are built with certain characteristics that may contribute to minimize the effects of two environmental pollution sources: leachate generation and biogas emission.

Sanitary landfill leachate is the resulting liquid from physical, chemical, and biodegradation processes of the putrescible organic fraction of municipal solid residues, in addition to rainwater percolating through landfill cells and moisture of grounded residues (RENOU et al., 2008).

For ABBAS et al. (2009), the leachate volume produced in a sanitary landfill depends on rainwater percolation through residues, biochemical processes in landfill cells, water percentage within residues, and residue compaction degree in the landfill. In general, leachate production is greater when residue is less compacted once compaction promotes decreasing water infiltration rate in landfill cells.

Qualitative composition of sanitary landfill leachates and contaminant concentration are changeable as they both depend on type of grounded municipal solid waste, solid residue stabilization degree, local hydrology, moisture, seasonal climatic variations, landfill age, and biodecomposition stage of grounded residues (ATMACA, 2009; SALEM et al., 2008; CABEZA et al., 2007).

The organic matter in sanitary landfill leachates includes, mainly, volatile fatty acids and humic substances. However, both organic fractions may widely vary, as they depend on landfill age. In recent sanitary landfills, the greatest part of organic carbon is found as volatile fatty acids. In landfills of more than 20 years, humic substances are basically composed of humic acids, fulvic acids, and humins, representing around 60\% of all leachate organic material (SÍR et al., 2012).

The treatment of sanitary landfill leachates certainly represents one of the main subjects to be considered at the project design, construction, and management stages of a sanitary landfill; for this reason, the environmental, technical, and economic variables must be considered (CALABRÒ et al., 2010).

According to OMAN \& JUNESTEDT (2008) and DENG \& ENGLEHARDT (2007), sanitary landfill leachates have significant concentrations of organic nature compound species, including biodegradable and refractory compounds with humic substances as an important group, as well as ammonia nitrogen, heavy metals, and organic and inorganic salts. These chemical compounds may cause problems to the environment if released without treatment, such as toxicity of the existing soil biota or aquatic community, and concentration decrease of the dissolved oxygen, favoring the eutrophication process in receiver water bodies.

The appropriate and economic treatment of sanitary landfill leachates has been a challenge for sanitary landfill operators because of the complexity to alter leachate characteristics (SINGH et al. 2012).

RENOU et al. (2008) affirm that, to achieve satisfactory conditions of sanitary landfill leachate release in receiver bodies, the appropriate treatment is necessary, which may be physical, chemical, biological, or combinations of them. It is worth mentioning that treatment success consists, among other factors, of leachate physical and chemical characterization, operational costs, and simplicity of the adopted method.

Among the adopted methods for ammonia nitrogen removal, the ammonia desorption is highlighted (KIM et al., 2005; LI et al., 2009). Such process has been widely used as it does not 
generate sludge and is of easy operation (ZHANG et al., 2012). It significantly reduces the ammonia nitrogen concentration, and favors biological post-treatment; thus, it also favors effluent release in receiver bodies as it promotes the production of effluents that meet legal environmental requirements for ammonia nitrogen concentration, of $20 \mathrm{mg} \mathrm{N} \mathrm{L}^{-1}$, as established by CONAMA in the Resolution 430/2011.

The ammonia desorption from sanitary landfill leachates has some advantages, as it is able to reach nitrogen discharge standards and is not sensitive to toxic substances. However, the main disadvantage of this process is associated with the environmental impact regarding $\mathrm{NH}_{3}$ gas release in the atmosphere. Therefore, further gas treatment is necessary using receptor solutions of $\mathrm{HCl}$ or with $\mathrm{H}_{2} \mathrm{SO}_{4}$ for capture of the released ammonia in the atmosphere, thus increasing operational costs of leachate treatment due to the use of chemical products (DI IACONI et al., 2010).

Desorption is a physical process of ammonia removal from the liquid gaseous phase mainly due to increase of the total contact surface of the aqueous phase with the surroundings (atmosphere), so that dragging effects and molecular diffusion may promote its transition to the latter (OZCURT et al., 1999). The free ammonia removal process from the liquid causes a balance shift towards its formation. Ammonia, in its aqueous phase, is balanced according to two forms, ionic $\left(\mathrm{NH}_{4}{ }^{+}\right)$and molecular gas $\left(\mathrm{NH}_{3}\right)$. Equation (1) shows the conversion balance from ammonium ion to ammonia gas.

$$
\mathrm{NH}_{4}^{+}(\mathrm{aq})+\mathrm{OH}^{-} \leftrightarrow \mathrm{NH}_{3}(\mathrm{~g})+\mathrm{H}_{2} \mathrm{O}(\mathrm{aq})
$$

Conversion balance depends on $\mathrm{pH}$; for $\mathrm{pH}$ around 7.2, balance tends to be shifted to the left. With $\mathrm{pH}$ increase, balance shifts to the right; thus, there is a greater increase of the gaseous fraction.

As concentration balance of ammonium ion and ammonia gas depends on $\mathrm{pH}$, the percentage distribution of ammonia and ammonium ion may be determined by eq.(2):

$$
\% \mathrm{NH}_{3}=\left[\mathrm{NH}_{3}\right] /\left(\mathrm{NH}_{3}+\mathrm{NH}_{4}^{+}\right) 100
$$

The air amount required to extract ammonia from wastewater is determined by the material balance equation under a stable equilibrium status for a dragging tower, as described by eq.(3) (KYOSAI \& RITTMANN, 1991).

$$
\mathrm{G}\left(\mathrm{y}_{2}-\mathrm{y}_{1}\right)=\mathrm{L}\left(\mathrm{x}_{2}-\mathrm{x}_{1}\right)
$$

where,

G - affluent gas mol per temperature unit (K);

$\mathrm{L}$ - affluent liquid mol per time unit (s);

$\mathrm{y}_{1}$ - gas solute concentration in the tower bottom area (mol solute $\mathrm{mol}^{-1}$ gas);

$\mathrm{y}_{2}$ - gas solute concentration in the tower top area (mol solute $\mathrm{mol}^{-1}$ gas);

$\mathrm{x}_{1}$ - liquid solute concentration in the tower bottom area (mol solute $\mathrm{mol}^{-1}$ liquid), and

$\mathrm{x}_{2}$ - liquid solute concentration in the tower top area (mol solute $\mathrm{mol}^{-1}$ liquid).

\section{MATERIAL AND METHODS}

The experiment was performed in the Laboratory of Environmental Sanitation, belonging to the Department of Sanitary and Environmental Engineering, Center of Sciences and Technology, State University of Paraíba, Brazil. For the desorption process, an experimental system was built, which was basically composed of: three desorption towers with $35.3 \mathrm{~L}$ capacity each; one tank for storage of in natura leachate; one device for correction of leachate $\mathrm{pH}$; one system for leachate release; and one system for air release.

A schematic diagram of the filling towers used for the ammonia desorption process is presented in Figure 1; Table 1 shows the applied operational parameters. This study was performed in filling towers with four treatments and three replications. 


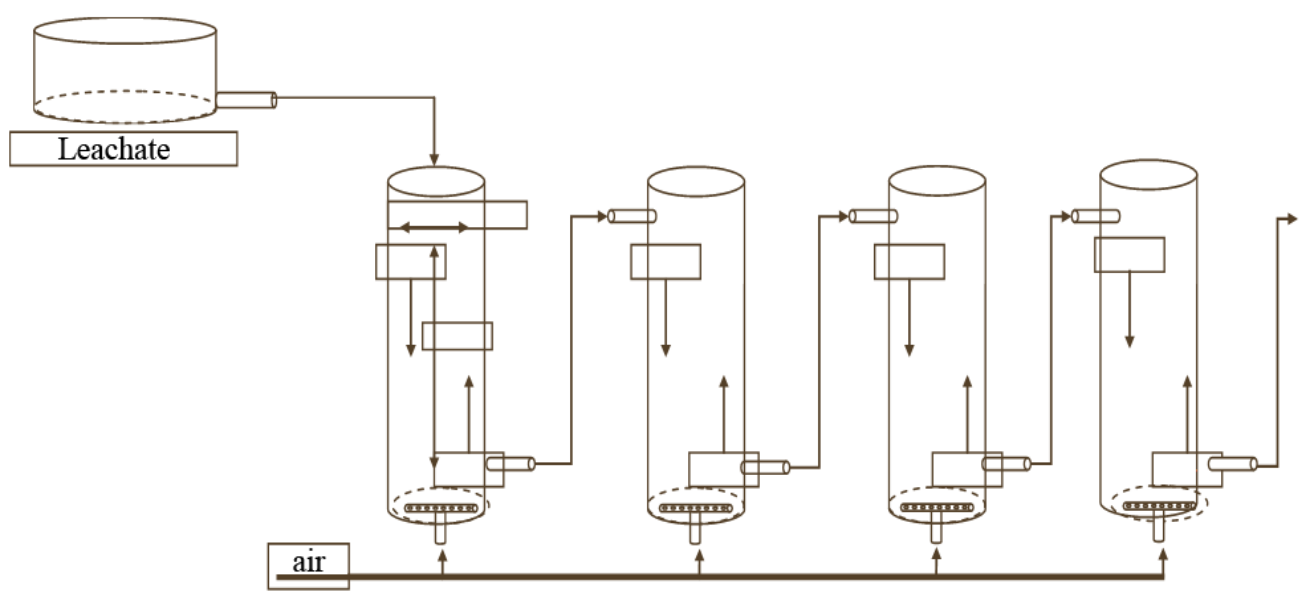

FIGURE 1. Schematic diagram of the filling towers.

TABLE 1. Operational data applied to the filling towers.

\begin{tabular}{cccccc}
\hline $\begin{array}{c}\text { Parameters/ } \\
\text { Treatments }\end{array}$ & $\begin{array}{c}\mathrm{V}_{\mathrm{T}} \\
(\mathrm{L})\end{array}$ & $\begin{array}{c}\mathrm{V}_{\mathrm{G}} \\
(\mathrm{L})\end{array}$ & $\begin{array}{c}\mathrm{V}_{\mathrm{L}} \\
(\mathrm{L})\end{array}$ & $\begin{array}{c}\mathrm{Q}_{\text {air }} \\
\left(\mathrm{m}^{3} / \mathrm{h}\right)\end{array}$ & $\mathrm{pH}$ \\
\hline 1 & 35.3 & 29 & 10 & 6.3 & 8 \\
2 & 35.3 & 29 & 10 & 6.3 & 9 \\
3 & 35.3 & 29 & 10 & 6.3 & 10 \\
4 & 35.3 & 29 & 10 & 6.3 & 11 \\
\hline
\end{tabular}

$\mathrm{V}_{\mathrm{T}}$ is the tower volume; $\mathrm{V}_{\mathrm{G}}$ is the gravel volume; $\mathrm{V}_{\mathrm{L}}$ is the leachate volume; $\mathrm{t}$ is the time; $\mathrm{Q}_{\mathrm{air}}$ is the applied air flow.

From the total tower volume, $82.1 \%$ was filled with class 4 gravel with $49 \%$ of empty space, what resulted in a total available volume of $20.5 \mathrm{~L}$ per tower. On average, only half of the available useful tower volume was taken by leachate, since the aeration process promotes a significant foam generation, thus dragging part of the leachate liquid. Air was released in the filling tower top area, while leachate was released in the bottom, which is a countercurrent procedure. Samples were collected every 30 minutes for determination of the following monitored analytical parameters: $\mathrm{pH}$, ammonia nitrogen, volatile fatty acids, and total alkalinity. The leachate released in the filling tower was collected from the municipal sanitary landfill of João Pessoa, Paraiba State, in Northeastern Brazil. It was collected in natura and transported in tanker cars to the Laboratory of Environmental Sanitation, belonging to the Department of Sanitary and Environmental Engineering, Center of Sciences and Technology, State University of Paraiba, which is located at a mean distance of 130 $\mathrm{km}$ from the sanitary landfill. Leachate was stored in closed reservoirs of rigid PVC and daily distributed to equalization tanks where $\mathrm{pH}$ was corrected before conducted to the towers. The $\mathrm{pH}$ correction was performed using sodium hydroxide and calcium hydroxide, with the objective to estimate the costs of the ammonia desorption process. For the analytical determinations, we considered the methods recommended by APHA (2005). The quantified chemical parameters and respective used analytical methods are presented in Table 2.

TABLE 2. Monitored chemical parameters and respective analytical methods.

\begin{tabular}{lll}
\hline Parameter & Analytical Method & Reference \\
pH & Potentiometry & APHA (2005) \\
Ammonia Nitrogen & MicroKjedahl & APHA (2005) \\
Total Alkalinity & Potentiometry & APHA (2005) \\
Volatile Fatty Acids & Potentiometry & APHA (2005) \\
\hline
\end{tabular}

For cost estimates of the two studied variables (chemical reagents and electricity, the following were considered:

1) Chemical reagents: price, in Brazilian currency $(R \$)$, of the used chemical reagents, and applied amount for leachate $\mathrm{pH}$ correction, for three treatments. 
2) Electricity: price, in Brazilian currency ( $R$ \$), was estimated according to compressor motor power, aeration mean time, local electricity price, and leachate volume released in each filling tower.

\section{RESULTS AND DISCUSSION}

Data of the leachate chemical characterization, used for the ammonia desorption process replications, are shown in Table 3 for four treatments.

TABLE 3. Chemical characterization data of in natura leachate used in the desorption process.

\begin{tabular}{lrc}
\hline Parameter & Magnitude & Unit \\
\hline pH & 8 & - \\
Total alkalinity & 14,291 & $\mathrm{mg} \mathrm{CaCO}_{3} \mathrm{~L}^{-1}$ \\
Volatile fatty acids & 5,907 & $\mathrm{mg} \mathrm{H}_{\mathrm{AC} \mathrm{L}}{ }^{-1}$ \\
Oxygen chemical demand (OCD) & 25,478 & $\mathrm{mg} \mathrm{O}_{2} \mathrm{~L}^{-1}$ \\
Oxygen biochemical demand (OBD) & 3,760 & $\mathrm{mg} \mathrm{O}_{2} \mathrm{~L}^{-1}$ \\
Total Kjeldahl nitrogen (TKN) & 4,881 & $\mathrm{mg} \mathrm{N} \mathrm{L}^{-1}$ \\
Ammonia nitrogen & 2,738 & $\mathrm{mg} \mathrm{N} \mathrm{L}^{-1}$ \\
Total solids (TS) & 25,490 & $\mathrm{mg} \mathrm{L}^{-1}$ \\
Total volatile solids (TVS) & 11,884 & $\mathrm{mg} \mathrm{L}^{-1}$ \\
Total suspended solids (TSS) & 644 & $\mathrm{mg} \mathrm{L}^{-1}$ \\
Volatile suspended solids (VSS) & 490 & $\mathrm{mg} \mathrm{L}^{-1}$ \\
Dissolved solids (DS) & 24,846 & $\mathrm{mg} \mathrm{L}^{-1}$ \\
Volatile dissolved solids (VDS) & 11,394 & $\mathrm{mg} \mathrm{L}^{-1}$ \\
Fixed dissolved solids (FDS) & 13,452 & \\
\hline
\end{tabular}

From the analysis of the data shown in Table 3, we observed that the leachate collected from the municipal sanitary landfill presented high ammonia nitrogen concentration and low OBD/OCD ratio when compared with domestic sewage and other liquid residues, what negatively contributes to the application of any biological treatment alternative. We also found that the leachate is basically composed of $2.5 \%$ total solids and $97.5 \%$ water, what is a 25 -time greater value than that found for domestic sewage. Another particularity that must be highlighted is that dissolved solids represent $72.1 \%$ of the total solid fraction, what is also a much higher value than in domestic sewage. Regarding the nitrogenous material, we verified that ammonia nitrogen concentration in the leachate was, on average, 54-time superior than in domestic sewage, what justifies the application of the ammonia desorption process for concentration decrease to a level that may enable biological treatment. Therefore, these particularities turn sanitary landfill leachates into wastewater that deserves special attention in the technical and scientific fields. The sanitary landfill leachate from João Pessoa, in comparison with leachates produced in another eight sanitary landfills in Southern, Southeastern, and Northeastern Brazil, presents the highest concentration of nitrogen and carbonaceous material. However, it has one of the lowest OBD/OCD ratios, what negatively contributes to biological treatment.

Because of the increasing production of solid residues, sanitary landfills are a real disposal alternative of municipal solid waste; thus, leachate production is unavoidable, so that the generation of a technological alternative for leachate treatment shall be priority. Therefore, an appropriate and economic treatment of sanitary landfill leachates has been a challenge for sanitary landfill operators because the complexity to alter leachate characteristics (SINGH et al., 2012). It is worth mentioning that the treatment success consists, among other factors, of leachate physical and chemical characterization, operational costs, and simplicity of the adopted method (RENOU et al., 2008).

Figure 2 shows temporal variation profiles of the parameters $\mathrm{pH}$, ammonia nitrogen, volatile fatty acids, and total alkalinity from treatment 1 ; leachate $\mathrm{pH}$ was adjusted to 8 . Profiles of three replications, with respective means, are presented for all parameters, except $\mathrm{pH}$. 
The behavior analysis of spatio-temporal variations indicated that the mean ammonia nitrogen concentration of the leachate used in treatment 1 was $2,050 \mathrm{mg} \mathrm{N} \mathrm{L}^{-1}$, which was reduced to lower values than $100 \mathrm{mg} \mathrm{N} \mathrm{L}^{-1}$ with a mean aeration time of 6 hours. The concentration decrease of the leachate ammonia nitrogen favors biological post-treatment; thus, it also favors effluent release in receiver bodies as it promotes the production of effluents that meet legal environmental requirements established by CONAMA in the Resolution 430/2011.
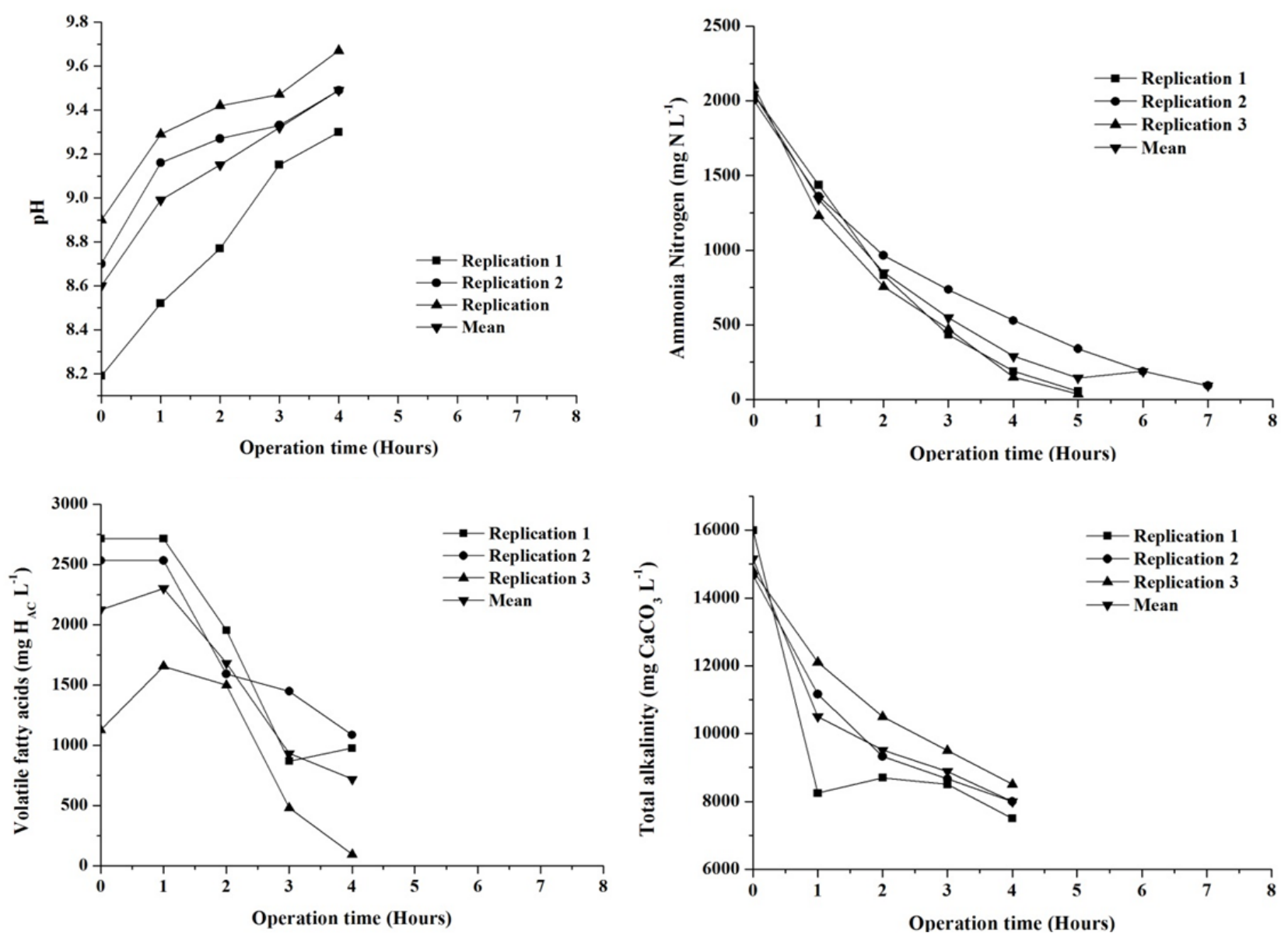

FIGURE 2. Profiles of the monitored parameters in treatment 1.

In wastewater of $\mathrm{pH} 8$, from the total ammonia nitrogen concentration, $94.7 \%$ is found as ammonium ion $\left(\mathrm{NH}_{4}{ }^{+}\right)$, and $5.3 \%$, as ammonia gas $\left(\mathrm{NH}_{3}\right)$. As the desorption process basically consists of removal of the most volatile components from the liquid medium via application of countercurrent air flow, it is recommended to apply the desorption process in wastewaters with a minimum $\mathrm{pH}$ 10.5. Under this value, ammonia gas concentration is $97 \%$ and will positively contribute to the desorption process efficiency; thus, it will also influence the ammonia nitrogen concentration decrease in the wastewater. The $\mathrm{pH}$ increased according to the decrease of ammonia nitrogen concentration, as the desorption process may also drag certain chemical species from the leachate chemical composition. In the ammonia desorption process, ammonium ion is converted into ammonia, consuming alkalinity, what justifies the initial concentration decrease from 15,100 to 7,900 mg $\mathrm{C}_{\mathrm{a}} \mathrm{CO}_{3} \mathrm{~L}^{-1}$. According to eq.(4), in quantitative terms, for each dissolved ammonium mol, there should be consumption of 1 milliequivalent of total alkalinity.

$$
\mathrm{NH}_{3}+\mathrm{H}^{+} \leftrightarrow \mathrm{NH}_{4}^{+}
$$

Total alkalinity concentration of the effluent leachate from the filling towers is, on average, 23-time greater than total alkalinity in domestic sewage produced by the population from Campina Grande, Paraíba State. As total alkalinity is basically composed of bicarbonate and volatile fatty acid alkalinity, a mean of $71 \%$ of the total alkalinity concentration in the sanitary landfill leachate from João Pessoa corresponds to bicarbonate alkalinity, and such percentage significantly increases 
in the filling tower effluents because of concentration decrease of volatile fatty acids. Regarding volatile fatty acids, leachate concentrations ranged from 1,128 to $2,715 \mathrm{mg} \mathrm{H}_{\mathrm{AC}} \mathrm{L}^{-1}$, and in the filling tower effluents, residual concentrations varied from 96 to $1,086 \mathrm{mg} \mathrm{H}_{\mathrm{AC}} \mathrm{L}^{-1}$. Concentration decrease of volatile fatty acids is favored by dragging certain chemical species from the liquid medium that have slightly acidic characteristics. In this treatment, specifically, which ammonia desorption process was performed in leachate with $\mathrm{pH}$ 8, only around 5.3\% was at its non-ionized form. Therefore, a longer interval is necessary so that the most representative part of ammonia nitrogen in the ionized form is converted into the non-ionized one, thus passing through desorption in the liquid medium. The theoretical relationship established among nitrogen species concentrations according to $\mathrm{pH}$ may be determined by eq.(5) (METCALF \& EDDY, 2003).

$$
\mathrm{pH}=9.25-\operatorname{logf}+\log \left[\mathrm{NH}_{3} / \mathrm{NH}_{4}{ }^{+}\right]
$$

where $\mathrm{f}$ is the activity coefficient.

Figure 3 presents profiles of temporal variations of the monitored parameters of three replications and respective means, from treatment 2. In this treatment, leachate $\mathrm{pH}$ was corrected to 9.
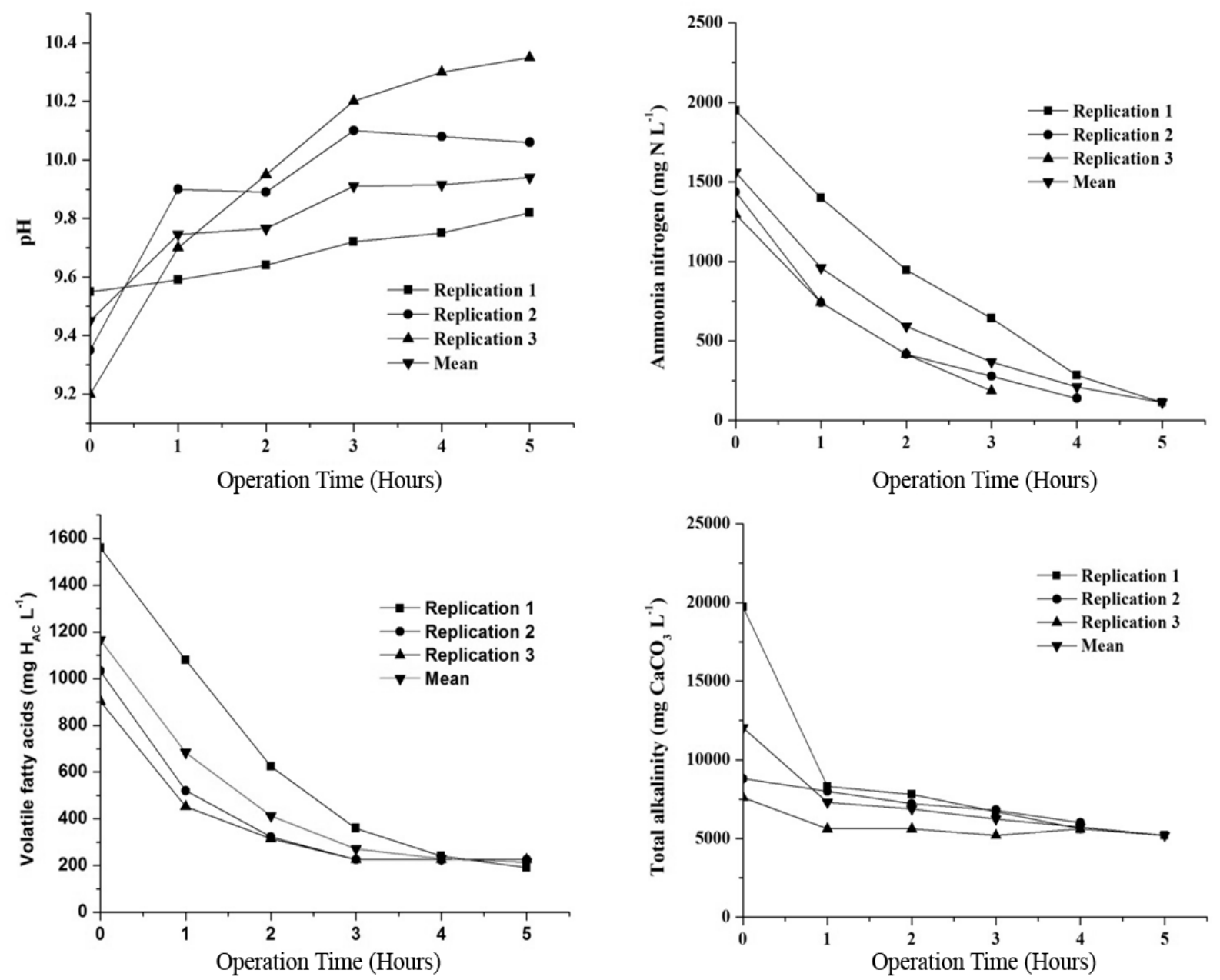

FIGURE 3. Profiles of the monitored parameters in treatment 2.

In treatment 2, the mean ammonia nitrogen concentration was reduced from 1,582 to $113 \mathrm{mg} \mathrm{N} \mathrm{L}^{-1}$, enabling a decrease efficiency of 93\%. For this treatment, specifically, from the total ammonia nitrogen concentration in the leachate released in the filling towers, $64.3 \%$ was in its ionic form $\left(\mathrm{NH}_{4}{ }^{+}\right.$), while the remaining (35.7\%), as ammonia gas, what favored the ammonia desorption process. Regarding $\mathrm{pH}$, there was a pronounced increase, from 9.2 to 10.4; under this $\mathrm{pH}$ value, from the total ammonia nitrogen concentration still present in the leachate at desorption process, a mean of $15.5 \%$ was in its ionic form. 
In this treatment, the mean concentration of volatile fatty acids was reduced from 1,128 to $192 \mathrm{mg} \mathrm{H}_{\mathrm{AC}} \mathrm{L}^{-1}$, with efficiency of 82.9\%. Such decrease is directly associated with removal, from the liquid medium, of certain chemical species that present characteristics of weak acids. However, a quantitative $\mathrm{pH}$ increase along the tower filling operation process was observed for all replications; this phenomenon has already been explained for treatment 1 . Total alkalinity concentration was reduced from 19,800 to $5,200 \mathrm{mg} \mathrm{CaCO}_{3} \mathrm{~L}^{-1}$, with efficiency of $73.7 \%$ associated directly with the ammonia desorption process. Such decrease may occur due to several processes, such as ammonia desorption, removal of volatile fatty acids, and in some situations, precipitation of calcium and magnesium salts.

In general, total alkalinity concentration decrease is strongly associated with the ammonia desorption process. It may be quantified by the difference among concentrations of total alkalinity in the in natura leachate released in the filling towers, and leachate concentration after desorption. Quantitatively, $14 \mathrm{mg} \mathrm{N} \mathrm{L}^{-1}$ contributes to the total alkalinity decrease of 1 meq $\mathrm{CaCO}_{3} \mathrm{~L}^{-1}$ or $50 \mathrm{mg} \mathrm{CaCO}_{3} \mathrm{~L}^{-1}$.

Figure 4 shows profiles of temporal variations of the monitored parameters in treatment 3. Leachate $\mathrm{pH}$ was corrected to 10 , and ammonia nitrogen concentrations used for the replications varied from 945 to $1,399 \mathrm{mg} \mathrm{N} \mathrm{L}^{-1}$.

This variation in ammonia nitrogen concentration occurs due to the time spent by the leachate with the corrected $\mathrm{pH}$; considering $\mathrm{pH} 10$, part of the converted ammonia nitrogen was released from the liquid medium before being released in the filling towers. In this treatment, a significant $\mathrm{pH}$ increase was not verified, once there was variation from 9.8 to 10.4.
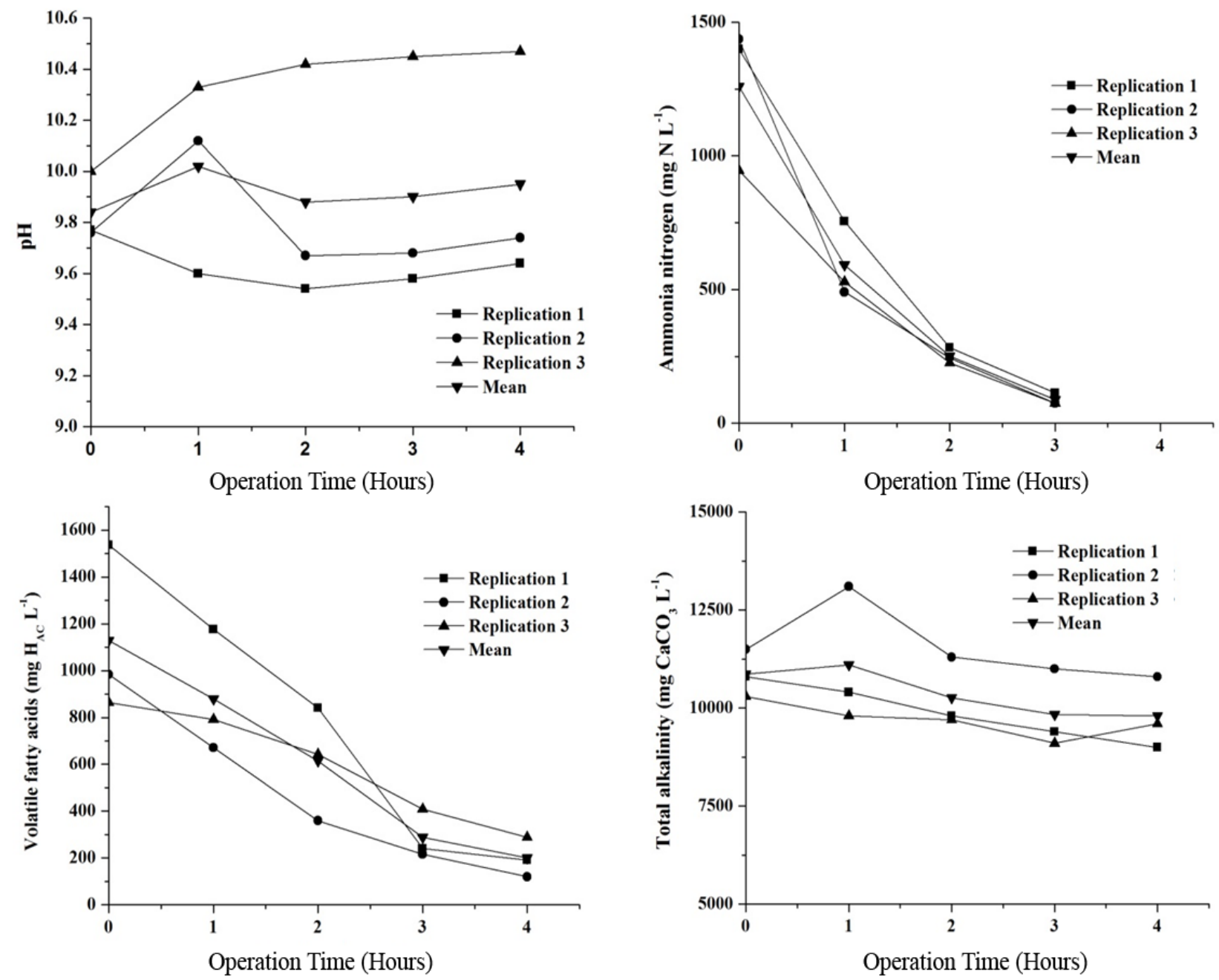

FIGURE 4. Profiles of the monitored parameters in treatment 3. 
We observed that, with three hours of monitoring, the ammonia nitrogen concentration decreased, on average, from 1,424 to $67 \mathrm{mg} \mathrm{N} \mathrm{L}^{-1}$, with efficiency of $95.4 \%$, which is a slightly higher value than the obtained for treatment 2. Concentration of volatile fatty acids was significantly reduced from 1,536 to $192 \mathrm{mg} \mathrm{H}_{\mathrm{Ac}} \mathrm{L}^{-1}$, with efficiency of $87.5 \%$ in the first replication. For the others, efficiency percentages were 75 and $86 \%$. Regarding the total alkalinity concentration, a low decrease efficiency was observed for all replications; such phenomenon is associated with the fundamentals already established.

Profiles of temporal variations of the monitored parameters and respective means are shown in Figure 5 for all replications of treatment 4.

For leachate of $\mathrm{pH} 11$, the initial ammonia nitrogen concentration ranged from 1,229 to $1,607 \mathrm{mg} \mathrm{N} \mathrm{L}^{-1}$. After the monitoring period of three hours, the residual ammonia nitrogen concentration varied from 56 to $70 \mathrm{mg} \mathrm{N} \mathrm{L}^{-1}$, with mean efficiency of $95.5 \%$. Regarding $\mathrm{pH}$, there was a small decrease for all replications, establishing around 10, what did not occur for the other treatments. Concentration of volatile fatty acids presented mean decrease efficiency of $68.6 \%$, while total alkalinity for the same $\mathrm{pH}$ showed small variations in concentration for all replications. For leachate $\mathrm{pH} 11,99 \%$ of total ammonia nitrogen concentration is already found as ammonia gas, what does not favor alkalinity consumption and positively contributes to ammonia nitrogen concentration decrease in the desorption process; furthermore, it also influences the decrease of the filling tower aeration time.
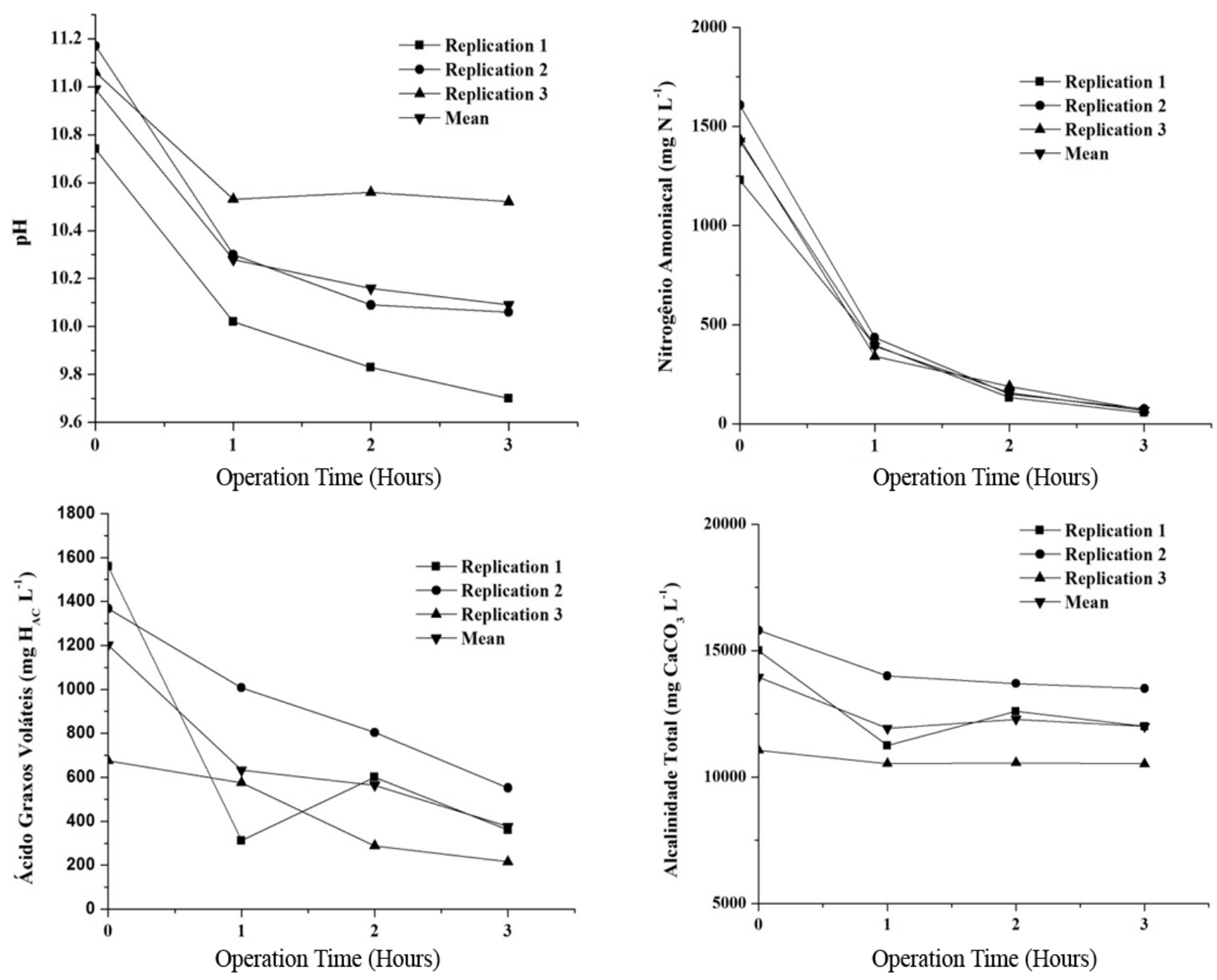

FIGURE 5. Profiles of the monitored parameters in treatment 4.

The ammonia desorption process from sanitary landfill leachate, performed in filling towers, significantly reduced the ammonia nitrogen concentration, favoring the application of a biological 
post-treatment, thus enabling effluent release in receiver bodies within the established legal standards.

For the ammonia desorption process from sanitary landfills, some parameters still need to be adjusted, such as operation of filling towers, $\mathrm{pH}$, and ammonia gas use.

Data of cost estimates of the leachate ammonia desorption process in filling towers are presented in Table 4. For cost estimating, we considered price of chemical species used for $\mathrm{pH}$ correction (sodium hydroxide and lime) and residential electricity fare charged by ENERGISA, the power company of Paraiba State.

TABLE 4. Cost estimates of the leachate ammonia desorption process.

\begin{tabular}{|c|c|c|c|c|c|c|}
\hline \multirow[b]{2}{*}{ Parameters } & \multicolumn{2}{|c|}{8.0} & \multicolumn{2}{|c|}{9.0} & \multicolumn{2}{|c|}{10.0} \\
\hline & $\begin{array}{c}\mathrm{NaOH} \\
\left(\mathrm{kg} \mathrm{m}^{-3}\right)\end{array}$ & $\begin{array}{c}\mathrm{Ca}(\mathrm{OH})_{2} \\
\left(\mathrm{~kg} \mathrm{~m}^{-3}\right)\end{array}$ & $\begin{array}{c}\mathrm{NaOH} \\
\left(\mathrm{kg} \mathrm{m}^{-3}\right)\end{array}$ & $\begin{array}{c}\mathrm{Ca}(\mathrm{OH})_{2} \\
\left(\mathrm{~kg} \mathrm{~m}^{-3}\right)\end{array}$ & $\begin{array}{c}\mathrm{NaOH} \\
\left(\mathrm{kg} \mathrm{m}^{-3}\right)\end{array}$ & $\begin{array}{c}\mathrm{Ca}(\mathrm{OH})_{2} \\
\left(\mathrm{~kg} \mathrm{~m}^{-3}\right)^{2}\end{array}$ \\
\hline Concentration & 0.091 & 0.141 & 1.2 & 4.9 & 2.9 & 5.8 \\
\hline Costs of alkalizers $\left(\mathrm{R} \$ \mathrm{~m}^{-3}\right)$ & 1.20 & 0.09 & 16.40 & 3.20 & 37.70 & 3.80 \\
\hline Costs of electricity $\left(\mathrm{R} \$ \mathrm{~m}^{-3}\right)$ & \multicolumn{2}{|c|}{69.00} & \multicolumn{2}{|c|}{63.00} & \multicolumn{2}{|c|}{44.00} \\
\hline$\overline{\text { Total costs }\left(\mathrm{R} \$ \mathrm{~m}^{-3}\right)}$ & 70.20 & 69.09 & 79.40 & 66.20 & 81.70 & 47.80 \\
\hline
\end{tabular}

Data presented in Table 4 indicate that, for $\mathrm{pH}$ 8, estimated costs for the leachate ammonia desorption process varied according to the filling tower aeration time and chemical species used for $\mathrm{pH}$ correction. Comparisons of costs associated with the chemical species used for $\mathrm{pH}$ increase showed that sodium hydroxide led to the highest cost for all treatments; in the case of treatment 1 , it was R 1.20 per leachate cubic meter while, for lime, it was only R 0.09 per leachate cubic meter. It is important to highlight that, for this $\mathrm{pH}$ level, 98\% of the total estimated costs correspond to electricity consumption. In general, even when lime was used for $\mathrm{pH}$ increase, specifically in this study, for each leachate cubic meter, $5.8 \mathrm{~kg}$ lime was used, resulting in a total cost of R $\$ 47.80$, what derails, both technically and financially, the ammonia desorption process.

\section{CONCLUSIONS}

The ammonia desorption process is more efficient when $\mathrm{pH}$ is higher than 10 . However, costs associated with $\mathrm{pH}$ increase from 7.8 to 10 are of $\mathrm{R} \$ 3.80$ per leachate cubic meter when the alkalizer species is lime, and of $\mathrm{R} \$ 37.70$ per leachate cubic meter when sodium hydroxide is used.

Efficiency of ammonia nitrogen removal in the filling towers was higher than $90 \%$ for all treatments. However, aeration time ranged from 3 to 6 hours, promoting ammonia nitrogen concentration around $100 \mathrm{mg} \mathrm{N} \mathrm{L}^{-1}$ in the leachate after desorption.

For sanitary landfill leachates with ammonia nitrogen concentration around 2,500 $\mathrm{mg} \mathrm{N} \mathrm{L}^{-1}$, the biological treatment is only feasible when the ammonia nitrogen concentration is decreased to an acceptable limit, which is very changeable. For the ammonia nitrogen concentration decrease, its desorption may be performed via filling tower, dilution process, or by slug flow reactors.

Specifically for this study, costs were estimated for three $\mathrm{pH}$ levels, two chemical alkalizer species, and aeration times ranging from 3.5 to 5.5 hours. We observed that, for leachate with $\mathrm{pH}$ around 10, ammonia nitrogen concentration decrease from 1,411 to $125 \mathrm{mg} \mathrm{N} \mathrm{L}^{-1}$, and aeration time of 5.5 hours, costs would be around $\mathrm{R} \$ 47.80$ per leachate cubic meter when the alkalizer species is lime, and R 81.70 per cubic meter when sodium hydroxide is used.

Considering the high ammonia nitrogen concentration in sanitary landfill leachates, application of the desorption process in filling towers will significantly contribute to the ammonia nitrogen concentration decrease, enabling the biological post-treatment; however, issues associated with costs should be considered. 
Considering sanitary landfill leachates as wastewaters of extremely complex physical and chemical composition, it is necessary, within the Brazilian situation, to reconsider sanitary landfills as disposal units of municipal solid waste, at least in the field of Sanitary Engineering.

\section{ACKNOWLEDGMENTS}

The authors thank FINEP/PROSAB and CNPq for financially supporting this project and granting several bursaries, which significantly contributed throughout the stages of this study.

\section{REFERENCES}

ABBAS, A. A.; JINGSONG, G.; PING, L. Z.; YA, P. Y.; AL-REKABI, W. S. Review on Landfill Leachate Treatments. American Journal of Applied Sciences, Adelaide, v. 6, n. 4, p. 672-684, 2009. APHA - American Public Health Association. Standard methods for examination of water and wastewater. $21^{\text {th }}$ ed., Washington: APHA, AWWA, WPCF, 2005.

ATMACA, E. Treatment of landfill leachate by using electro-Fenton method. Journal of Hazardous Materials, Amsterdam, v. 163, n. 1, p. 109-114, 2009.

CABEZA, A.; URTIAGA, A.; RIVERO, M. J.; ORTIZ, I. Ammonium removal from landfill leachate by anodic oxidation. Journal of Hazardous Materials, Amsterdam, v. 144, n. 3, p. 715-719, 2007.

CALABRÓ, P. S.; SBAFFONI, S.; ORSI, S.; GENTILI, G.; MEONI, C. The landfill reinjection of concentrated leachate: Findings from a monitoring study at an Italian site. Journal of Hazardous Materials, Amsterdam, v. 181, n. 1-3, p. 962-968, 2010.

CASTRILLÓN, L.; NAVA, F.; ULMANU, M.; ANGER, I.; MARAÑÓN, E. Physico-chemical and biological treatment of MSW landfill leachate. Waste Management, Oxford, v. 30, n. 2, p. 228-235, 2010.

COTMAN, M.; GOTVAJN, A. Z. Comparison of different physico-chemical methods for the removal of toxicants from landfill leachate. Journal of Hazardous Materials, Amsterdam, v. 178, n. 1-3, p. 298-305, 2010.

CONAMA - Conselho Nacional de Meio Ambiente. Legislação Ambiental Federal, Resolução n ${ }^{\circ}$ 430/2011. Disponível em:< http://www.cetesb.sp.gov.br/Agua/praias/res_conama_430> Acesso em: 10 maio 2012.

DENG, Y.; ENGLEHARDT, J. D. Electrochemical oxidation for landfill leachate treatment. Waste Management, Amsterdam v. 27, n. 3, p. 380-388, 2007.

DI IACONI, C.; PAGANO, M.; RAMADORI, R.; LOPEZ, A. Nitrogen recovery from a stabilized municipal landfill leachate. Bioresource Technology, v. 101, n. 6, p. 1732-1736, 2010.

KIM, K. W.; KIM, Y. J.; KIM, I. T.; PARK, G. I.; LEE, E. H. The electrolytic decomposition mechanisms of ammonia to nitrogen at an $\mathrm{IrO}_{2}$ anode. Electrochimica Acta, New York, v. 50, n. 22, p. 4356-4364, 2005.

KYOSAI, S.; RITTMANN, B.E. Effect of water-surface desorption on volatile compound removal under bubble aeration. Research Journal Water Pollution Control Federation, v. 63, n. 6, 1991, p.10-15.

LEITE, V. D.; PEARSON, H. W.; SOUSA, J. T.; LOPES, W. S.; LUNA, M. L. The removal of ammonia from sanitary landfill leachate using a series of shallow waste stabilization ponds. Water Science \& Technology, Oxford, v. 63, n.4, p. 666 - 670, 2011.

LI, M.; FENG, C.; ZHANG, Z.; LEI, X.; CHEN, R.; YANG, Y.; SUGIURA, N. Simultaneous reduction of nitrate and oxidation of by-products using electrochemical method. Journal of Hazardous Materials, Amsterdam, v. 171, n. 1-3, p. 724 -730, 2009. 
METCALF \& EDDY. Wastewater Engineer: treatment disposal, reuse. $4^{\text {a }}$ ed. New York: McGRaw-Hill Book, 2003.

MOHAJERI, S.; AZIZ, H. A.; ISA, M. H.; BASHIR, M. J. K.; MOHAJERI, L.; ADLAN, M. N. Influence of Fenton reagent oxidation on mineralization and decolorization of municipal landfill leachate. Journal Environmental Science Health, New York, v.45, n. 6, p. 692-698, 2010.

OMAN, C. B.; JUNESTEDT, C. Chemical characterization of landfill leachates - 400 parameters and compounds. Waste Management, Oxford, v. 28, n. 10, p. 1876-1891, 2008.

OZCURT, I.; ALTINBAS, M.; ARIKAN, O. Pollution problems of sanitary landfill leachat and treatment techniques. In: CIVIL MANAGEMENT, HUMAN AND ENVIROMENTAL PROBLEMS SYMPOSIUM, 1999, Istambul, Turkey. Proceedings...

RENOU, S.; GIVAUDAN, J. G.; POULAIN, S.; DIRASSOUYAN, F.; MOULIN,P. Landfill leachate treatment: Review and opportunity. Journal of Hazardous Materials, Amsterdam, v. 150, n. 3, p. 468-493, 2008.

SALEM, Z.; HAMOURI, K.; DJEMMA, R.; ALLIA, K. Evaluation of landfill leachate pollution and treatment. Desalination, Amsterdam, v. 220, n. 1-3, p. 108-114, 2008.

SINGH, S. K.; TOWNSEND, T. G.; MAZYCK, D.; BOYER, T. H. Equilibrium and intra-particle diffusion of stabilized landfill leachate onto micro- and meso-porous activated carbon. Water Research, New York, v. 46, n. 2, p. 491-499, 2012.

SÍR, M.; PODHOLA, M.; PATOCKA, T.; HONZAJKOVÁ, Z.; KOCUREK, P.; KUBAL, M.; KURAS, M. The effect of humic acids on the reverse osmosis treatment of hazardous landfill leachate. Journal of Hazardous Materials, Amsterdam, v. 207-208, p. 86-90, 2012.

UMAR, M.; AZIZ, H. A.; YUSOFF, M. S. Trends in the use of Fenton, electro-Fenton and photoFenton for the treatment of landfill leachate. Waste Management, Oxford, v.30, n. 11, p. 2113-2121, 2010.

YE, J.X.; MU, Y.J.; CHENG, X.; SUN, D.Z. Treatment of fresh leachate with high-strength organics and calcium from municipal solid waste incineration plant using UASB reactor. Bioresource Technology, Essex, v. 102, n. 9, p. 5498-5503, 2011.

ZHANG, L.; LEE, Y. W.; JAHNG, D. Ammonia stripping for enhanced biomethanization of piggery wastewater. Journal of Hazardous Materials, Amsterdam, v. 199-200, p. 36-42, 2012. 